\title{
Investigating the adipokine and cardiac troponin response in experimental thyroid dysfunction
}

\author{
Bülent Bayraktar ${ }^{1 *}$, Emre Tekce ${ }^{2}$, Çiğdem Takma ${ }^{3}$, Sevil Bayraktar ${ }^{4}$, Ayten A. Kilinç55, \\ Ufuk Ülker ${ }^{6}$, and Efe Kurtdede ${ }^{7}$
}

\author{
${ }^{1}$ Faculty of Health Sciences, Bayburt University, Bayburt, Turkey \\ ${ }^{2}$ Faculty of Applied Sciences, Bayburt University, Bayburt, Turkey \\ ${ }^{3}$ Department of Animal Science, Faculty of Agriculture, Ege University, Izmir, Turkey \\ ${ }^{4}$ Department of physiology, Ondokuz Mayls University, Samsun, Turkey \\ ${ }^{5}$ Directorate of Poultry Research Institute, Ankara, Turkey \\ ${ }^{6}$ Veterinary Control Center Research Institute, Ankara, Turkey \\ ${ }^{7}$ Faculty of Veterinary Medicine, Ankara University, Ankara, Turkey
}

BAYRAKTAR, B., E. TEKCE, Ç. TAKMA, S. BAYRAKTAR, A. A. KILINÇ, U. ÜLKER, E. KURTDEDE:
Adipokine and cardiac troponin response in experimental thyroid dysfunction. Vet. arhiv 90, 289-296, 2020. ABSTRACT

This study was conducted to investigate adipokine [Apelin and brain-derived neurotrophic factor (BDNF)] and cardiac troponin (cTnI) response that emerged after adding an essential oil mixture (EOM) (Eucalytus glabutus labii, Thymus vulgaris, Cymbopogon nardus, and Syzygium aromaticum) at different rates to the drinking water of broilers in which thyroid dysfunction (hypo- and hyperthyroidism) had been experimentally induced. In the present study, 150 1-day-old Ross-308 male broiler chicks were used. They were divided into five groups, each with 30 animals. The groups were designed to include five subgroups: control (C), hypothyroid, hypothyroid $+250 \mathrm{ppm}$ EOM, hyperthyroid, and hyperthyroid $+250 \mathrm{ppm}$ EOM, with six animals in each group. At the end of the experiment, Apelin, p-BDNF, cTnI, T3, T4, and thyroid-stimulating hormone (TSH) levels were investigated in blood serum samples obtained by cervical dislocation from four randomly selected animals from each subgroup, making 100 animals in total. It was found that EOM administration resulted in a dose-dependent increase in p-BDNF and apelin levels, and a decrease in T4 levels in the experimentally induced hypo- and hyper-thyroidism groups, but did not affect T3 and cTnI levels. Conversely, an increase in TSH level was observed in the hypothyroidism groups, whereas a decrease was observed in groups with hyperthyroidism. This study is the first to examine adipokine (Apelin and BDNF) and cTnI response to EOM administration in thyroid dysfunction.

Key words: apelin; brain-derived neurotrophic factor; cardiac troponin; essential oil mixture; thyroid dysfunction; broiler chicks

\section{Introduction}

The thyroid is an essential endocrine gland that it is the only organ that requires iodine to function. has a vital role in regulating all body functions, and

T4 (thyroxine) and calcitonin hormones are secreted

\footnotetext{
*Corresponding author:

Assist. Prof. Bülent Bayraktar, Department of Physiotherapy and Rehabilitation, Faculty of Health Sciences, Bayburt University, Bayburt 69000, Turkey, Phone: +90 0458333 2047; E-mail: bulentbayraktar@bayburt.edu.tr
} 
regularly from the thyroid gland into the blood. The T4 hormone is converted to T3 (triiodothyronine) by nonthyroid tissues, and the thyroid-stimulating hormone (TSH) is responsible for its secretion. TSH is a $28-30 \mathrm{kDa}$ hormone synthesized in the anterior pituitary, and controls the functioning of the thyroid gland. The measurement of TSH level is the most sensitive method in the evaluation of thyroid function in poultry (SCHMIDT and REAVILL, 2008; HULBERT, 2000).

Thyroid hormones ensure the development and function of all tissues and organs. Besides, the thyroid is also defined as the center of energy balance, as it increases the sensitivity of all tissues, especially the heart, to catecholamines (WARNER and MITTAG, 2012; MULLUR et al., 2014; McANINCH and BİANCO, 2014). Thyroid hormone levels must be within a specific range in the blood so that these functions can be maintained. An increase in thyroid hormone levels in the blood is referred to as hyperthyroidism, whereas a decrease in these levels is referred to as hypothyroidism (SARANAC et al., 2011; SZKUDLİNSKİ et al., 2002).

Apelin is an adipokine, secreted from a fatty tissue that controls thermogenesis and thyroid gland functions, and is vital in many physiological processes (TATEMOTO et al., 2001); MATSUZAWA, 2005). Apelin has several isoforms, such as $12,13,17$, and 36 . The biological activity of Apelin-13 is eight times stronger than that of Apelin-17 and 60 times stronger than that of Apelin-36 (TATEMOTO et al., 1998). Although apelin is present in the hypothalamus and thyroid gland, studies on its role in the hypothalamuspituitary thyroid axis are limited in number (YANG et al., 2019).

Conversely, one of the organs most vulnerable to thyroid hormone deficiency in living beings is the brain (SANTISTEBAN and BERNAL, 2005; WILLIAMS, 2008). This is because thyroid hormones have a critical role in the development and functioning of the brain (DE ESCOBAR et al., 2004; Lİ et al., 2019). Plasma BDNF (p-BDNF) is defined as a sensitive marker indicating the BDNF level in the brain (LOMMATZSCH et al., 2005). $\mathrm{BDNF}$ is an adipokine with a neuroprotective effect against neuron development and differentiation, as well as stress and ischemia in the brain (ZIGOVA et al., 1998; BENRASIS et al., 2001; KERTES et al., 2017).

Moreover, thyroid hormones are vital in regulating cardiac function and for cardiac repair to be performed (PANTOS and MOUROUZISS, 2015; VON HAFE et al., 2019). Therefore, the heart is an essential organ in maintaining the balance of thyroid hormones (GERDES and OJAMAA, 2011). In fact, there is a relationship between thyroid dysfunction and cardiovascular diseases; hypothyroidism leads to impaired heart function and heart failure (LIUU et al., 2019). cTnI is reported as the most sensitive and specific indicator in the assessment of cardiovascular diseases and cardiac function, especially in the detection of myocardial damage (UNDHAD et al., 2012; MONNERET et al., 2019). Besides, the hormones Apelin and BDNF also have regulatory roles in cardiac contraction (SZOKODI et al., 2002; FULGENZI et al., 2015). Essential oils have a vital role in regulating thyroid gland activity. Lemon oil has been reported to support thyroid gland function (STEWART, 2005). Thyme and clove oils, which constitute the basis of our study, also have regulatory effects on thyroid gland function (İLI, 2003; STEWART, 2005).

This study aimed to determine the adipokine (Apelin and BDNF) and cardiac troponin (cTnI) response to the use of an essential oil mixture (EOM) in broilers with experimentally induced thyroid dysfunction (hypo- and hyperthyroidism).

\section{Materials and methods}

Animals. Ethical approval was obtained from the Local Ethics Committee of Ankara Etlik Veterinary Control Centre Research Institute Directorate, Turkey, dated 14.11.2018 and numbered 2018/08. In this study, 150 1-day-old Ross-308 male broiler chicks were used. The study was conducted in line with the ethical principles and rules protecting animal welfare and rights.

Experimental design. The study was conducted at the poultry unit in the Food, Agriculture, and Animal Husbandry Practice and Research Centre Unit at Bayburt University. The study continued for 
B. Bayraktar et al.: Investigating the adipokine and cardiac troponin response in experimental thyroid dysfunction

a total of 42 days, with 7 days of acclimation and 35 days of fattening. At the end of the acclimation period, the chicks were divided into groups of 30 in separate $110 \times 110 \times 100 \mathrm{~cm}$ compartments with underlay. The average live weights of the chicks in each group were the same. Each group consisted of five subgroups (control (C), hypothyroid (Hypo), hypothyroid + 250 ppm EOM, hyperthyroid (Hyper), and hyperthyroid $+250 \mathrm{ppm}$ EOM) with six chicks in each group. Addition of propylthiouracil (6-propyl-2-thiouracil; PTU) and levothyroxine (L-T4) to poultry feed was used to induce hypothyroidism and hyperthyroidism experimentally in the poultry (PEEBLES et al., 1992).

Further, $0.4 \mathrm{mg} / 100 \mathrm{~g}$ of levothyroxine sodium (L-T4; Sigma, USA) was added to the broiler feed of the hyperthyroidism group, and $0.2 \%$ propylthiouracil (PTU; Sigma, USA) was added to the feed of the hypothyroidism group (PEEBLES and MARKS, 1991; PEEBLES et al., 1992; PEEBLES et al., 1994). The medications used in this study included sodium levothyroxine and 6-N-propyl-2-thiouracil (PTU), purchased from Turkey. All other chemicals were of analytical grade or purer; $250 \mathrm{ppm}$ EOM was added to the drinking water of the Hypo and Hyper groups.

Poultry house heat moisture and illumination. While the broiler chicks were given water ad libitum, the ration content used in their nutrition is given in Table1. Feed and EOM added water for the study groups were added at the same time each day. Analysis of feed given to the animals was carried out according to the methods described in A.O.A.C (AOAC, 2005). During the training period, the lighting applied to the chicks was 24 hours $(60 \mathrm{~W})$ and the heating is $0-7.7-42$ day, at a temperature of $27-28^{\circ} \mathrm{C}$.

Contents of the EOM mixture. During the study, broiler EOM mixture was added to the drinking water produced by a commercial company (Ankara, Turkey). The mixture was analyzed by GC (Gas Chromatography) in Bayburt University Central Research Laboratories. The content of essential oil mixture was found to be $26.70 \%$ Durenol, 23.89\% Eugenol, 16.49\% Gamma terpinene, $8.35 \%$ Hieptaethylene glycol, $6.42 \%$ Hexaethylene glycol,
3.31\% Cymene, 3,08\% Pentaethylene glycol, $2.87 \%$ Caryophyllene, 2.30\% D-Limonene, 2.18\% Betapinene and $0.95 \%$ Eucalyptol.

Table 1. Basal diet ration nutrient content and analyzes (g/kg)

\begin{tabular}{|c|c|c|c|}
\hline Raw material & $\begin{array}{l}\text { Starter } \\
(0-14 \mathrm{~d})\end{array}$ & $\begin{array}{l}\text { Grower } \\
(14-28 \mathrm{~d})\end{array}$ & $\begin{array}{l}\text { Finisher } \\
(28-42 \mathrm{~d})\end{array}$ \\
\hline Maize & 52.70 & 54.60 & 58.12 \\
\hline Maize gluten feed & 15.21 & 21.19 & 26.14 \\
\hline Soybean residue & 26.35 & 18.90 & 10.65 \\
\hline $\begin{array}{l}\text { Dicalcium } \\
\text { phosphate }\end{array}$ & 1.95 & 1.70 & 1.60 \\
\hline Calcium carbonate & 1.18 & 1.10 & 1.04 \\
\hline Sodium chloride & 0.31 & 0.31 & 0.31 \\
\hline $\begin{array}{l}\text { Sodium } \\
\text { bicarbonate }\end{array}$ & 0.20 & 0.20 & 0.20 \\
\hline Salt & 0.2 & 0.2 & 0.2 \\
\hline Methionine & 0.50 & 0.50 & 0.44 \\
\hline Lisin & 1.20 & 1.10 & 1.10 \\
\hline $\begin{array}{l}\text { Vitamin-mineral } \\
\text { premix }^{1}\end{array}$ & 0.20 & 0.20 & 0.20 \\
\hline ME (kcal/ kg) & 3100 & 3150 & 3225 \\
\hline Crude Protein \% & 24 & 22 & 20 \\
\hline Crude Oil \% & 2.61 & 2.30 & 2.50 \\
\hline $\mathrm{ASH} \%$ & 5.19 & 4.63 & 3.85 \\
\hline Moisture $\%$ & 13.20 & 13.20 & 13.20 \\
\hline
\end{tabular}

Vitamin-mineral premix content (per kg of diet): vitamin A, 12 $000 \mathrm{IU}$; vitamin D3, $1500 \mathrm{IU}$; vitamin E, $35 \mathrm{mg} / \mathrm{kg}$; vitamin $\mathrm{K} 3,5 \mathrm{mg} / \mathrm{kg}$; vitamin B1, $3 \mathrm{mg}$; vitamin B2, $4 \mathrm{mg}$; vitamin B6, $4 \mathrm{mg}$; vitamin B12, $0.03 \mathrm{mg}$; calcium-D-pantothenate, $15 \mathrm{mg}$; folic acid, $1 \mathrm{mg}$; niacin, $25 \mathrm{mg}$; D-biotin, $0.115 \mathrm{mg}$; $\mathrm{Mg} 80 \mathrm{mg} /$ $\mathrm{kg}$; I, 0,15 mg/kg; Co, $0.2 \mathrm{mg} / \mathrm{kg}$; Cu, $5 \mathrm{mg} / \mathrm{kg}$; Fe, $60 \mathrm{mg} / \mathrm{kg}$; $\mathrm{Se}, 1 \mathrm{mg} / \mathrm{kg} ; \mathrm{Zn}, 60 \mathrm{mg} / \mathrm{kg}$.

Collection of serum samples. At the end of the trial, 10 animals, randomly selected from each group, which is 80 animals in total, were categorized by taking $10 \mathrm{~mL}$ tubes of blood to perform biochemical blood analysis during cervical dislocation. The blood from the animals was refrigerated and centrifuged (NF 1200, CORE, Ankara, Turkey) $+4{ }^{\circ} \mathrm{C}$ for 12 minutes to obtain serum samples in Eppendorf tubes.

Measurement of serum Apelin levels. The minimum detectable concentration used to measure the Apelin level in blood serum obtained from the research was $<18.75 \mathrm{pg} / \mathrm{mL}$. An ELISA kit was 
used, type-specific for chicken Apelin (FineTest, Product code: ECH0078, China), from 31.25$2000.00 \mathrm{pg} / \mathrm{mL}$, with an intra-assay coefficient of $8.0 \%$, and an inter-assay coefficient of $10.0 \%$, in accordance with the manufacturer's protocol. The results were evaluated by reading absorption values at $450 \mathrm{~nm}$, in accordance with the procedure reported in the kit.

Measurement of serum cTnIlevels. The minimum detectable concentration needed to measure serum cTnI levels in blood serum obtained from the study was $<9.4 \mathrm{pg} / \mathrm{mL}$. An ELISA kit, type-specific for chicken cTnI was utilized (FineTest, Product code: ECH0069, China), from 15.6-1000.00 pg/ $\mathrm{mL}$, with an intra-assay coefficient of $8.0 \%$, and an inter-assay coefficient of $10.0 \%$, in accordance with the manufacturer's protocol. The results were evaluated by reading absorption values at $450 \mathrm{~nm}$ in accordance with the procedure reported in the kit.

Measurement of Plasma BDNF Levels. A commercially available chicken BDNF (Sunred,

\section{Results}

Tables 2 and 3 below show data on thyroid hormone levels (T3, T4, TSH) as well as Apelin, BNDF, and cTnI levels among broilers with experimentally induced hypo- and hyper-thyroidism after adding EOM.

When thyroid hormone levels were examined, it was found that T4 levels were highest in the Hyper and Hyper + EOM-250 PPM groups, compared with the control group (31.74 and $29.48 \mathrm{ng} / \mathrm{mL}$, respectively), and they were lowest in the Hypo
Product code: 201-16-1172, China) ELISA kit was utilized by reading $450 \mathrm{~nm}$ absorbance values in accordance with the procedure reported in the kit.

Thyroid Hormone (T3, T4, and TSH) measurements. T3 (Lot No: 1006125590), T4 (Lot No: 1006123200), and TSH (Lot No: 1006156500) measurements in chicken blood serum samples were studied using enzyme-linked fluorescence assay (ELFA; Mini-Vidas instrument, France), comprising a compact automated immunoassay method based on the principles of ELFA with an auto analyzer.

Statistical analysis. The measures were all normally distributed, and data are expressed as means and standard errors of the mean. The univariate general linear model was used to identify differences between the four diet groups. Duncan multiple comparison tests were applied to compare differences between means. All statistical tests were performed at $5 \%$ level of statistical significance by IBM SPSS statistics 20.0

and Hypo+EOM-250 ppm groups (15.63 and 18.97 $\mathrm{ng} / \mathrm{mL}$, respectively), and these differences were statistically significant $(\mathrm{P}<0.05)$. T3 levels were found to be highest in the Hypo and Hypo + EOM250 PPM groups (2.74 and $2.67 \mathrm{ng} / \mathrm{mL}$, respectively) and lowest in the Hyper and Hyper + EOM-250 PPM groups (2.69 and $2.46 \mathrm{ng} / \mathrm{mL}$, respectively), compared with the control group. However, these results were not statistically significant.

Table 2. Changes in serum thyroid hormone levels (Mean \pm SE) due to EOM administration in experimental groups $(\mathrm{ng} / \mathrm{mL})$

\begin{tabular}{|l|c|c|c|}
\hline & T3 $(\mathrm{ng} / \mathrm{mL})$ & T4 $(\mathrm{ng} / \mathrm{mL})$ & TSH $(\mathrm{ng} / \mathrm{mL})$ \\
\hline Control & $2.55 \pm 0.32^{\mathrm{ab}}$ & $23.24 \pm 2.06^{\mathrm{c}}$ & $2.01 \pm 0.36^{\mathrm{c}}$ \\
\hline Hyper & $2.69 \pm 0.13^{\mathrm{ab}}$ & $31.74 \pm 3.15^{\mathrm{a}}$ & $1.21 \pm 0.10^{\mathrm{d}}$ \\
\hline Hypo & $2.74 \pm 0.15^{\mathrm{a}}$ & $15.63 \pm 1.72^{\mathrm{e}}$ & $3.56 \pm 0.39^{\mathrm{a}}$ \\
\hline Hyper + EOM-250 PPM & $2.46 \pm 0.23^{\mathrm{b}}$ & $29.48 \pm 1.82^{\mathrm{b}}$ & $1.32 \pm 0.13^{\mathrm{d}}$ \\
\hline Hypo + EOM-250 PPM & $2.67 \pm 0.21^{\mathrm{ab}}$ & $18.97 \pm 1.13^{\mathrm{d}}$ & $2.76 \pm 0.26^{\mathrm{b}}$ \\
\hline P & 0.07 & 0.00 & 0.00 \\
\hline
\end{tabular}

a,b,c,d: Differences between values bearing different letters on the same line are significant $(\mathrm{P}<0.05)$. 
B. Bayraktar et al.: Investigating the adipokine and cardiac troponin response in experimental thyroid dysfunction

Table 3. Comparison of Apelin, BDNF, cTnI hormone levels (Mean \pm SE) as a result of EOM application in experimental groups

\begin{tabular}{|l|c|c|c|}
\hline & Apelin $(\mathrm{ng} / \mathrm{mL})$ & BDNF $(\mathrm{ng} / \mathrm{mL})$ & cTnI $(\mathrm{ng} / \mathrm{mL})$ \\
\hline Control & $1.41 \pm 0.30^{\mathrm{c}}$ & $2.14 \pm 0.27^{\mathrm{c}}$ & $1.14 \pm 0.14^{\mathrm{ab}}$ \\
\hline Hyper & $1.86 \pm 0.59^{\mathrm{b}}$ & $2.32 \pm 0.20^{\mathrm{bc}}$ & $1.00 \pm 0.11^{\mathrm{b}}$ \\
\hline Hypo & $2.57 \pm 0.44^{\mathrm{a}}$ & $2.73 \pm 0.58^{\mathrm{ab}}$ & $1.28 \pm 0.53^{\mathrm{ab}}$ \\
\hline Hyper+EOM-250 PPM & $2.10 \pm 0.44^{\mathrm{b}}$ & $2.65 \pm 0.48^{\mathrm{ab}}$ & $1.25 \pm 0.45^{\mathrm{ab}}$ \\
\hline Hypo+EOM-250 PPM & $2.79 \pm 0.56^{\mathrm{a}}$ & $3.03 \pm 0.63^{\mathrm{a}}$ & $1.41 \pm 0.41^{\mathrm{a}}$ \\
\hline $\mathrm{p}$ & 0.00 & 0.00 & 0.16 \\
\hline
\end{tabular}

a,b,c: Differences between values bearing different letters on the same line are significant $(\mathrm{P}<0.05)$.

Thyroid hormone levels were lowest in the Hypo and Hypo+EOM-250 PPM groups (3.56 and $2.76 \mathrm{ng} / \mathrm{mL}$, respectively) and highest in the Hyper and Hyper+EOM-250 PPM groups (1.21 and 1.32 $\mathrm{ng} / \mathrm{mL}$, respectively), compared with the control group, and these differences were statistically significant $(\mathrm{P}<0.05)$.

The most significant increase in Apelin, BDNF, and cTnI hormone levels in the experimental groups, compared with those in the control group, was found in the Hypo + EOM-250 PPM group.

\section{Discussion}

This study was designed to investigate the effect of the addition of EOM on serum Apelin, BDNF, and cTnI levels in broilers with experimentally induced hypo- and hyper-thyroidism, and the usability of these measured parameters as biomarkers of thyroid dysfunction.

Apelin receptors are localized in the thyroid gland. Conversely, TSH and thyroid hormone receptors are found within the adipose tissue. Therefore, possible changes in thyroid hormone levels also affect the release of adipokines (GÜREL et al., 2015). The serum Apelin levels obtained in the present study were consistent with those of other studies reporting an increase in hypothyroidism (GÜLER et al., 2015; AHMED et al., 2018), whereas other studies reported contradictory results (AKHONDALI et al., 2015; SHAHRIVAR et al., 2016; YAŞAR et al., 2019). The increase in Apelin levels in the hypothyroidism groups was attributed to the decreased lipolysis that accompanied the decreasing basal metabolism (VENDITTI and DI
However, the increase in cTnI was not statistically significant. The highest Apelin, BDNF, and CTnI levels in the experimental groups were 2.79, 3.03, and $1.41 \mathrm{ng} / \mathrm{mL}$ respectively in the Hypo + EOM250 PPM group. Similarly, the lowest Apelin and BDNF levels were determined as 1.41 and $2.14 \mathrm{ng} /$ $\mathrm{mL}$, respectively, in the control group $(\mathrm{P}<0.05)$, and the lowest cTnI level was measured as $1.00 \mathrm{ng} / \mathrm{mL}$ in the Hyper group. However, these results were not statistically significant.

MEO, 2006; GREDILLA et al., 2001). Conversely, the BDNF levels obtained in the present study were consistent with those in other studies reporting an increase in hypothyroidism (CORTÉS et al., 2012), but differed from the results of GILBERT and LASLEY, 2013. This increase in the BDNF levels is thought to occur due to the response to cellular stress and the neuroprotective effect of BDNF (CORTÉS et al., 2012). Besides, we believe that the results obtained from this study present sufficient evidence to consider p-BNDF as a biomarker in the evaluation of thyroid hormone metabolism in the brain.

The cTnI levels obtained in the Hypo and Hypo + EOM-250 PPM groups were consistent with those in other studies reporting an increase in hypothyroidism (JANSEN et al., 2019; HOSSEIN et al., 2018; GÜREL et al., 2015; BIONDI, 2007; PEEBLES et al., 1994; AL WAKEEL et al., 2019; TEKIEH et al., 2019). Furthermore, it has been reported that there are difficulties in diagnosing 
B. Bayraktar et al.: Investigating the adipokine and cardiac troponin response in experimental thyroid dysfunction

cardiac damage due to thyroid dysfunction (LIU et al., 2019).

Therefore, we believe that cTnI, which is considered to be the most sensitive indicator of cardiac damage, can be used as a biomarker in the evaluation of myocardial damage caused by thyroid dysfunction.

\section{Conclusion}

In conclusion, in experimentally induced hypoand hyperthyroidism, EOM administration had a dose-dependent effect on adipokine response (Apelin and p-BDNF), but did not affect cardiac troponin response. The fact that thyroid hormone levels returned to normal after EOM administration shows that EOM has a positive effect on thyroid gland function. Investigating the relationship between thyroid hormones and adipokines is expected to make a valuable contribution to explaining the underlying physiological mechanisms of many metabolic diseases, such as diabetes. According to the review of the literature, the present study is the first and only study conducted on this issue. Therefore, further studies are needed to support the hypothesis and results of this study.

\section{Conflicts of interest}

The authors declare that there are no conflicts of interest.

\section{References}

AHMED, A., A. B. D. AL-RAOF, M. YASSER (2018): Role of changes in some adipokines with obesity in relation to thyroid function in early diagnosed patients with subclinical hypothyroidism. Med. J. Cairo. Univ. 86,4657-4665.

DOI: 10.21608/MJCU.2018.65748

AKHONDALI, Z., M. BADAVI, M. DIANAT, F. FARAJI (2015): Co-administration of Apelin and T4 protects inotropic and chronotropic changes occurring in hypothyroid rats. Arq. Bras. Cardiol. 105, 235-240.

DOI: $10.5935 /$ abc. 20150086

AL WAKEEL, R. A., M. F. SAAD, A. ABDEL AZEEZ, F. ELKHIAT, M. SHUKRY (2019): Both experimental hypoand hyper-thyroidism exacerbate the adverse effects of chronic heat stress in broilers. Br. Poult. Sci. 3, 1-10.

DOI:10.1080/00071668.2019.1602248

AOAC (2005): Official Methods of Analysis of AOAC International. $18^{\text {th }}$ ed. Rockville, MD, USA: Association of Official Analytical Chemists.
BENRASIS, A., E. CHMIELNICKI, K. LERNER., D. ROH., S. A. GOLDMAN (2001): Adenoviral brain-derived neurotrophic factor induces both neostriatal and olfactory neuronal recruitment from endogenous progenitor cells in the adult forebrain. J. Neurosci. 21, 6718-6731.

DOI: $10.1385 / \mathrm{MN}: 31: 1-3: 231$

BIONDI, B. (2007): Cardiovascular effects of mild hypothyroidism. Thyroid. 17, 625-630.

DOI: $10.1089 /$ thy.2007.0158

CORTÉS, C., E. EUGENIN, E. ALIAGA, L.J. CARREÑO, S.M. BUENO, P.A.D. GONZALEZ, C.A. ROSENTHAL (2012): Hypothyroidism in the adult rat causes incremental changes in brain-derived neurotrophic factor, neuronal and astrocyte apoptosis, gliosis, and deterioration of postsynaptic density. Thyroid. 22, 951-963.

DOI: $10.1089 /$ thy.2010.0400

DE ESCOBAR, G. M., M. J. OBREGÓN, F. E. DEL REY (2004): Maternal thyroid hormones early in pregnancy and fetal brain development. Best Pract. Res. Clin. Endocrinol. Metab.18, 225-248.

DOI: $10.1016 /$ j.beem.2004.03.012

FULGENZI, G., F. TOMASSONI-ARDORI, L. BABINI, J. BECKER, C. BARRICK, S. PUVEREL, L. TESSAROLLO (2015): BDNF modulates heart contraction force and longterm homeostasis through truncated TrkB. T1 receptor activation. J. Cell Biol. 210, 1003-1012.

DOI: $10.1083 /$ jcb.201502100

GERDES, A. M., A. K. OJAMAA (2011): Thyroid hormone and cardioprotection. Compr. Physiol. 6, 1199-1219.

DOI: $10.1002 /$ cphy.c150012

GREDILLA, R., G. BARJA, M. LÓPEZ-TORRES (2001): Thyroid hormone-induced oxidative damage on lipids, glutathione and DNA in the mouse heart. Free Radic. Res. $35,417-425$.

DOI:10.1080/10715760100300931

GILBERT, M. E., S. M. LASLEY (2013): Developmental thyroid hormone insufficiency and brain development: a role for brain-derived neurotrophic factor (BDNF). Neuroscience 239, 253-270.

DOI: 10.1016/j.neuroscience.2012.11.022

GÜREL, A., A. DOĞANTEKIN, Y. ÖZKAN, S. AYDIN (2015): Serum apelin levels in patients with thyroid dysfunction. Int. J. Clin. Exp. Med. 8, 16394-16398. PMID: 26629164

HOSSEIN, N., P. KAZEM, D. DELARAM, H.R. NASIM, N. MOHAMMAD (2018): Effect of maternal hypothyroidism on BDNF expression in developing rat brain. J. Mol. Biol. Res. 8, 31-40.

DOI: $10.5539 /$ jmbr.v8n1p31

HULBERT, A.J. (2000): Thyroid hormones and their effects: A new perspective. Biol. Rev. 75, 519-631.

DOI: $10.1017 / \mathrm{s} 146479310000556 \mathrm{x}$ 
B. Bayraktar et al.: Investigating the adipokine and cardiac troponin response in experimental thyroid dysfunction

İLİ, P. (2003): Chemical contents of some medicinal plants and its effects on animals. Master's Thesis, Pamukkale University Institute of Science (in Turkish).

JANSEN VAN VUREN, E., L. MALAN, R. VON KÄNEL, M. MAGNUSSON, L. LAMMERTYN, N. T. MALAN (2019): BDNF increases associated with constant troponin $\mathrm{T}$ levels and may protect against poor cognitive interference control: The SABPA prospective study. Eur. J. Clin. Invest. 49, 1-10.

DOI: $10.1111 /$ eci.13116

KERTES, D. A., S. S. BHATT, H. S. KAMIN, D. A. HUGHES, N. C. RODNEY, C. J. MULLIGAN (2017): BNDF methylation in mothers and newborns is associated with maternal exposure to war trauma. Clin Epigenetics. 9, 6890. PMID: 28680507.

LI, J., K. ABE, A. MILANESI, Y.Y. LIU, G.A. BRENT (2019): Thyroid hormone protects primary cortical neurons exposed to hypoxia by reducing dna methylation and apoptosis. Endocrinology 160, 2243-2256.

DOI: 10.1210/en.2019-00125.

LIUU, M., W. LIUU, P. ZHANG, J. AN, G. WANG (2019): Left ventricular myocardial $\mathrm{T} 1$ mapping and strain analysis evaluate cardiac abnormality in hypothyroidism. Int. J. Cardiovasc Imaging. 35, 507-515.

DOI: $10.1007 / \mathrm{s} 10554-018-1456-4$

LOMMATZSCH, M., D. ZINGLER, K. SCHUHBAECK, K. SCHLOETCKE, C. ZINGLER, P. SCHUFF-WERNER, J. C. VİRCHOW (2005): The impact of age, weight and gender on BDNF levels in human platelets and plasma. Neurobiol. Aging 26, 115-123.

DOI: 10.1016/j.neurobiolaging.2004.03.002

MATSUZAWA, Y. (2005): Adipocytokines and metabolic syndrome. Semin. Vasc. Med. 5, 34-38.

DOI: $10.1055 / \mathrm{s}-2005-871744$

McANINCH, E. A., A. C. BIANCO (2014): Thyroid hormone signaling in energy homeostasis and energy metabolism. Ann. Ny. Acad Sci.1311,77-87.

DOI: $10.1111 /$ nyas. 12374

MONNERET, D., M. GELLERSTEDT, F. ROCHE, D. BONNEFONT-ROUSSELOT (2019): Outlier removal methods for skewed data: impact on age-specific highsensitive cardiac troponin $\mathrm{T} 99^{\text {th }}$ percentiles. Clin. Chem. Lab. Med. 57, e244-e247.

DOI: $10.1515 / \mathrm{cclm}-2018-1366$

MULLUR, R., Y. Y. LIU, G.A. BRENT (2014):Thyroid hormone regulation of metabolism. Physiol. Rev. 94, 355382.

DOI: 10.1152 /physrev.00030.2013

PANTOS, C., I. MOUROUZIS (2015): Translating thyroid hormone effects into clinical practice: the relevance of thyroid hormone receptor $\alpha 1$ in cardiac repair. Heart Fail Rev. 20, 273-282.

DOI: $10.1007 / \mathrm{s} 10741-014-9465-4$
PEEBLES, E. D., H. İ. MARKS (1991): Effects of selection on plasma thyroxine concentrations in Japanese Quail under thiouracil and protein stress. Poult. Sci. 70, 641-650.

DOI: $10.3382 / \mathrm{ps} .0700641$

PEEBLES, E. D., E. H. MILLER, C. R. BOYLE, J. D. BRAKE, M.A. LATOUR (1994): Effects of dietary thiouracil on thyroid activity, egg production, and eggshell quality in commercial layers. Poult. Sci. 73, 1829-1837.

DOI: $10.3382 /$ ps.0731829

PEEBLES, E. D., E. H. MILlER, J. D. BRAKE, C. D. SCHULTZ (1992): Effects of ascorbic acid on plasma thyroxine concentrations and eggshell quality of leghom chickens treated with dietary thiouracil. Poult Sci. 71, 553559.

DOI: $10.3382 / \mathrm{ps} .0710553$

SANTISTEBAN, P., J. BERNAL (2005): Thyroid development and effect on the nervous system. Rev. Endocr. Metab. Dis. 6, 217-228.

DOI: $10.1007 / \mathrm{s} 11154-005-3053-9$

SARANAC, L., S. ZIVANOVIC, B. BJELAKOVIC, H. STAMENKOVIC, M. NOVAK, B. KAMENOV (2011): Why is the thyroid so prone to autoimmune disease? Horm. Res. Paediatr.75, 157-165.

DOI: $10.1159 / 000324442$

SCHMIDT, R. E., D. R. REAVILL (2008): The avian thyroid gland. Vet. Clin. North Am. Exot. Anim. Pract. 11, 15-23.

DOI: 10.1016/j.cvex.2007.09.008

SHAHRIVAR, F. F., M. BADAVI, M. DIANAT, A. MARD, A. AHANGARPOUR, M. HEDAYATI, A. SAMARBAFZADEH (2016): Comparison of therapeutic effects of L-Thyroxin, apelin and a combination of both on antioxidant enzymes in the heart of PTU-induced hypothyroid rats. Braz. Arch. Biol. Technol. 59,1-8.

DOI: 10.1590/1678-4324-2016150585

STEWART, D. (2005): The Chemistry of Essential Oils made simple: God's Love Manifest in Molecules. $1^{\text {th }}$ ed., Care Marble Hill. Mo., USA, pp. 55-59.

SZKUDLINSKI, M. W., V. FREMONT, C. RONIN, B. D. WEINTRAUB (2002): Thyroid-stimulating hormone and thyroid-stimulating hormone receptor structure-function relationships. Physiol. Rev. 82, 473-502.

DOI: 10.1152 /physrev.00031.2001

SZOKODI, I., P. TAVI, G. FÖLDES, S. VOUTILAINENMYLLYLÄ, M. ILVES, H. TOKOLA, H. RUSKOAHO (2002): Apelin, the novel endogenous ligand of the orphan receptor APJ, regulates cardiac contractility. Circ. Res.91, 434-440.

DOI: 10.1161/01.res.0000033522.37861.69

TATEMOTO, K., M. HOSOYA, Y. HABATA, R. FUJI, T. KAKEGAWA, M. X. ZOU, T. KUROKAWA (1998): Isolation and characterization of a novel endogenous 
B. Bayraktar et al.: Investigating the adipokine and cardiac troponin response in experimental thyroid dysfunction

peptide ligand for the human APJ receptor. Biochem. Bioph. Res. Co. 251, 471-476.

DOI: $10.1006 /$ bbrc.1998.9489

TATEMOTO, K., K. TAKAYAMA, M. X. ZOU, I. KUMAKI, W. ZHANG, K. KUMANO, M. FUJIMIYA (2001): The novel peptide apelin lowers blood pressure via a nitric oxide-dependent mechanism. Regul. Pept. 99, 87-92.

DOI: 10.1016/s0167-0115(01)00236-1

TEKIEH, M. F., F. ESFAHANIAN, F. EMADI, M. GHOLAMI, E. EMARATKAR (2019): Effect of Nigella sativa on thyroid function in patients with hypothyroidism treated with levothyroxine: a triple-blind randomized controlled trial. Med. Sci. 23, 606-614. PMID: 27852303

UNDHAD, V. V., D. T. FEFAR, B. M. JIVANI, H. GUPTA, D. J. GHODASARA, B. P. JOSHI, K. S. PRAJAPATI (2012):

Cardiac troponin: an emerging cardiac biomarker in animal health. Vet. World. 5, 508-511.

DOI: $10.5455 /$ vetworld.2012.508-511

VENDITTI, P., S. DI MEO (2006): Thyroid hormone-induced oxidative stress. Cell Mol. Life Sci. 63, 414-434.

DOI: $10.1007 / \mathrm{s} 00018-005-5457-9$

VON HAFE, M., J. S. NEVES, C. VALE, M. BORGESCANHA, A. LEITE-MOREIRA (2019): The impact of thyroid hormone dysfunction on ischemic heart disease. Endocr Connect. 8, R76-R90. PMID: 30959486.
WARNER, A., J. MITTAG (2012): Thyroid hormone and the central control of homeostasis. J. Mol. Endocrinol. 49, R29-R35.

DOI: 10.1530/JME-12-0068

WILLIAMS, G. R (2008): Neurodevelopmental and neurophysiological actions of thyroid hormone. J. Neuroendocrinol. 20, 784-794.

DOI: $10.1111 / j .1365-2826.2008 .01733 . x$

YANG, N., T. LI, J. CHENG, Q. TUO, J. SHEN (2019): Role of apelin/APJ system in hypothalamic-pituitary axis. Clin. Chim. Acta. 499, 149-153.

DOI: 10.1016/j.cca.2019.09.011

YASAR, H. Y., M. DEMIRPENCE, A. COLAK, L. YURDAKUL, M. ZEYTINLİ, H. TURKON, F. EKINCİ, A.GÜNASLAN, E. YASAR (2019). Serum iris and apelin levels and markers of atherosclerosis in patients with subclinical hypothyroidism. Arch. Endocrinol. Metab. 63, 16-21 (In Turkish).

DOI: $10.20945 / 2359-3997000000106$

ZIGOVA, T., V. PENCEA, S. J. WIEGAND, M. B. LUSKIN (1998): Intraventricular administration of BDNF increases the number of newly generated neurons in the adult olfactory bulb. Mol. Cell Neurosci. 11, 234-245.

DOI: $10.1006 /$ mcne.1998.0684

Received: 2 August 2019

Accepted: 17 March 2020

\section{BAYRAKTAR, B., E. TEKCE, Ç. TAKMA, S. BAYRAKTAR, A. A. KILINÇ, U. ÜLKER, E. KURTDEDE: Odgovor adipokina i srčanog troponina na eksperimentalno izazvanu disfunkciju štitne žlijezde brojlera. Vet. arhiv 90, 289-296, 2020.}

\section{SAŽETAK}

Cilj rada bio je istražiti odgovor adipokina [apelin i moždani neurotrofni faktor (BDNF)] i srčanog troponina (cTnI) nakon dodavanja različitih omjera mješavine esencijalnih ulja (EOM) (Eucalytus glabutus labii, Thymus vulgaris, Cymbopogon nardus i Syzygium aromaticum) u vodu za piće brojlerima kojima je eksperimentalno izazvana disfunkcija štitnjače (hipotireoidizam i hipertireoidizam). U istraživanju je upotrijebljeno 150 jednodnevnih muških brojlera Ross-308. Podijeljeni su u pet skupina po 30 jedinki. Skupine su osmišljene tako da uključe i pet podskupina sa po šest brojlera: kontrolna skupina (C), hipotireoidna, hipotireoidna s $250 \mathrm{ppm}$ mješavine esencijalnih ulja, hipertireoidna i hipertireoidna s $250 \mathrm{ppm}$ mješavine esencijalnih ulja. Na kraju istraživanja u krvnom su serumu analizirane razine apelina, p-BDNF-a, cTnI-ja, T3, T4 i tireoidnog stimulacijskog hormona (TSH) koji su dobiveni cervikalnom dislokacijom od četiriju nasumično odabranih jedinki iz svake podskupine, što je činilo ukupno 100 životinja. Zapaženo je da je primjena EOM-a uzrokovala porast razina p-BDNF-a i apelina i smanjenje razine T4 u skupinama u kojima su eksperimentalno izazvani hipotireoidizam i hipertireoidizam, ali nije utjecala na razine T3 i cTnI-ija. Nasuprot tomu, u skupinama s hipotireoidizmom zabilježen je porast razine TSH-a, dok je smanjenje razine zabilježeno u skupinama s hipertireoidizmom. Ovo je prvo istraživanje odgovora adipokina (apelina i BDNF-a) i cTnI-ija na primjenu mješavine esencijalnih ulja kod brojlera s disfunkcijom štitne žlijezde.

Ključne riječi: apelin; moždani neurotrofni faktor; srčani troponin; mješavina esencijalnih ulja; disfunkcija štitne žlijezde; brojleri 